\title{
Interaction of magma and wet, unconsolidated sediments: a case study from Ilindenski Kamak, Chelopech Formation, Central Srednogorie
}

\section{Взаимодействие между магма и влажни, неконсолидирани седименти: пример от Илинденски камък, Челопешка свита, Централно Средногорие}

\author{
Stefan Velev, Ianko Gerdjikov, Dian Vangelov \\ Стефан Велев, Янко Герджиков, Диан Вангелов \\ Sofia University "St. Kliment Ohridski”, Faculty of Geology and Geography, 1504 Sofia, Bulgaria; \\ E-mails: velev@gea.uni-sofia.bg; janko@gea.uni-sofia.bg; dedo@gea.uni-sofia.bg
}

\begin{abstract}
The Ilindenski Kamak is situated along the Ilindenska river valley, northwest of Chelopech village, and is composed of different types of volcanic and volcaniclastic rocks, which are interbedded by sandstones and mudstones, all of Late Cretaceous age. The architecture of the pile of extrusive andesitic rocks is interpreted as a subaqueous cryptodome or sill. The presented research deals with a variety of volcanic facies: 1, coherent andesitic domain; 2, quench fragmented domain (closely packed peperites); 3, globular peperites developed at the contact of wet, unconsolidated sediments.
\end{abstract}

Keywords: subaqueous volcanism, peperite, volcanostratigraphy.

\section{Introduction}

Interaction of magma and wet, unconsolidated sediments is a process typical for environments, where sedimentation accompanies magmatism and/or volcanism, especially for subaqueous settings, where large volumes of magma are emplaced as synvolcanic intrusions, sills or cryptodomes. In this article we describe a case study of non-explosive magmawater interaction developed in subaqueous setting in the so-called Chelopech Formation.

\section{Geological setting}

Chelopech area is a classical locality for the investigation of the Late Cretaceous stratigraphy and relations between magmatism and sedimentation. The Upper Cretaceous rocks cropped out along the southern slope of Stara Planina Mountain are known as "Chelopech strip" (Bončev, 1940). The southern part of the sequence is overturned and often imbricated (Antonov et al., 2010), while the northern one is represented by shallow south-dipping monocline, result of the late
Alpine tectonic overprint. In this contribution we are presenting field data from the well-outcropped domain to the NW of Chelopech magmatic center, an area that preserve intact features indicative of the style and environments of magma emplacement.

Despite the extensive research due to the presence of the Chelopech ore deposit, a lot of questions regarding stratigraphy and the genetic interpretation of the sedimentary and magmatic rocks remain still open. For long years the time span of the magmatism and associated volcaniclastic/epiclastic sedimentation used to be regarded as a long-lasting one, continuing more than few million years (e.g. Moev, Antonov, 1978). Recently, on the basis of micropaleontological data (Stoykov, Pavlishina, 2004) and U-Pb zircon dating (Stoykov et al., 2004) it has become obvious that the magmatism in Chelopech area is represented by three pulses, all with Turronian age ( 92-91 Ma), a time span confirmed by Chamberfort et al. (2007). Importantly, despite the extensive research, there is only one recent paper describing in detail genesis of the volcaniclastic and volcano-sedimentary deposits (Chamberfort, Moritz, 2014). 


\section{The Chelopech Formation}

The so-called Chelopech Formation (Moev, Antonov, 1978) includes almost the entire spectrum of sedimentary, volcano-sedimentary and intermediate volcanic rocks with irregular lateral relationship and stratification.

The sedimentary and volcano-sedimentary rocks vary from very fine pelitic to psammitic and psephitic with fast lateral changes. The sedimentary structures indicate redeposition in short distances. They can be interpreted as SSDS (Syn-Sedimentary Deformation Structures), result of extensional tectonic or seismic activity or both but in any case, marking short-lasting events.
In the area of Ilindenski Kamak the deeply incised Ilindenska River valley provides perfect outcrops to study relations between lowermost part of the Chelopech Formation and the magmatic rocks related to the distal part of the Chelopech magmatic center. Here, a big igneous body with eventually andesitic composition crop out at Ilindenski Kamak area. The igneous rocks are grey, with porphyritic texture. Main part of the phenocrysts are plagioclase and rare pyroxenes. The facies and morphology of the body are still controversial. Based on field data the body can be interpreted as a cryptodome or as a sill. The cryptodome (sill) has irregular, interfingering with the host sediments, including intricate interactions between the magma and sediments (Fig. 1).
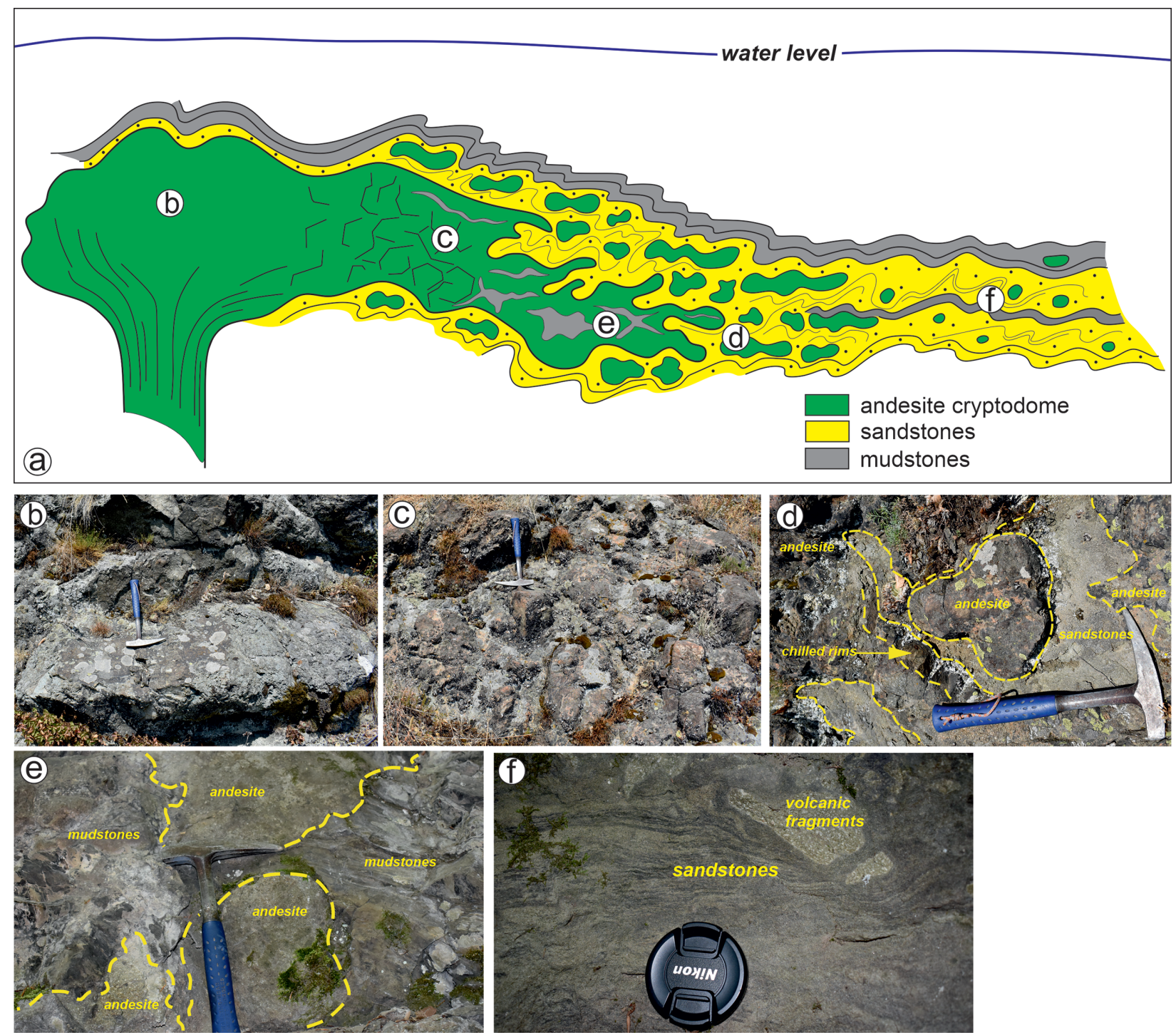

Fig. 1. Intrusion of a cryptodome in non-consolidated sediments at Ilindenski Kamak (coordinates: 24, 041084190; 42, 716841062): $a$, idealized sketch of the Ilindenski Kamak outcrop; $b$, coherent domain; $c$, quench fragmented domain (autobreccias) passed to closely packed peprites; $d$, sheroidal and lobe-like peperites; $e$, polyhedral joint (block) of mudstones in andesite matrix; $f$, sediment, matrix-rich breccias 
The penetration of magma into the unconsolidated sediments results in quench fragmentation (autobrecciation) and generation of in situ peperites (Fig. 1). After the classification of BusbySpera and White (1987) the peperites from Ilindenski Kamak are mainly globular (fluidal). The magma clasts are lensoidal, bulbous, lobate, cauliflower etc., and vary in size from centimeter to decimeter (Fig. 1). Globular clasts are thought to form in cases, where a water-vapour film is established and maintained at the interface of the magma with the sediments. Globular peperite is more likely to develop in the host sediments, which are fine-grained, well sorted, because these are more permissive to fluid flow and more easily fluidized. In peperitic facies, sandstones and/or mudstones fill joints and fractures that define lobelike bodies (Fig. 1d, e), polyhedral joint (blocks) and closely packed fabrics (Fig. 1c), or sediment, matrix-rich breccia (Fig. 1f). Often, the andesite fragments have chilled rims (Fig. 1d). Along some contacts (NE from Ilindenski Kamak), peperites with dispersed fabric pass through a zone of closely packed peperite (autobrecciation domain) (Fig. 1c), and respectively closely packed peperites pass into coherent facies (Fig. 1b). The complexities of peperite in respect to clast types, abundances and distribution, as well as grain-size and structures in the sedimentary component, suggest that a spectrum of fragmentation and mixing processes were involved. At Ilindenski Kamak, the peperite is formed by a combination of: i) non-explosive oscillation of vapour films at the magmasediment interface; ii) non-explosive expansion of pore-water following enclosure of sediment in the magma or entrapment of sediment at the magmasediment contacts.

\section{Conclusions}

The outcrops at Ilindenski Kamak locality provide world-class example of interaction of the intermediate magma with uncosolidated sediments. While some of the peperite superficially resembles polymictic epiclastic breccias and conglomerates, the well outcropped key area allows to document transition from coherent magmatic facies to sediment- dominated rocks, thus recording interaction between magma and not lithified sediments.

The synchronous to the magmatic activity deposits and the interactions between soft sediment and magma need to be investigated in more details. The characteristics of the Chelopech Formation require revision of this stratigraphic interval, but applying the rules of the volcanostratigraphy, not only conventional lithostratigraphy.

Acknowledgements: The study is funded by the National Program "Young Scientists and Postdoctoral Students, 2021" at the Ministry of Education and Science.

\section{References}

Antonov, M., S. Gerdjikov, L. Metodiev, H. Kiselinov, V. Sirakov, V. Valev. 2010. Explanatory Note to the Geological Map of the Republic of Bulgaria, Scale 1:50 000, Map Sheet K-35-37-B (Pirdop). Sofia, Ministry of Environment and Water, Bulgarian National Geological Survey, $47 \mathrm{p}$.

Bončev, E. 1940. Über die Geologie des Bajlovo Teiles der Panagjurishte-Zone der Srednogorie unter Berücksichtigung der Tektonik dieser Zone. - Rev. Bulg. Geol. Soc., 11, 205-238.

Busby-Spera, C. J., J. D. L. White. 1987. Variation in peperite textures associated with differing host-sediment properties. - Bull. Volcanol., 49, 765-775; https://doi.org/10.1007/ BF01079827.

Chambefort, I., R. Moritz, A. von Quadt. 2007. Petrology, geochemistry and $\mathrm{U}-\mathrm{Pb}$ geochronology of magmatic rocks from the high-sulfidation epithermal $\mathrm{Au}-\mathrm{Cu}$ Chelopech deposit, Srednogorie zone, Bulgaria. - Miner. Deposita, 42, 665-690; https://doi.org/10.1007/s00126-007-0126-6.

Chambefort, I., R. Moritz. 2014. Subaqueous environment and volcanic evolution of the Late Cretaceous Chelopech $\mathrm{Au}-\mathrm{Cu}$ epithermal deposit, Bulgaria. - J. Volcan. Geoth. Res., 289, 1-13; https://doi.org/10.1016/j.jvolgeores.2014.10.013.

Moev, M., M. Antonov. 1978. Stratigraphy of the Upper Cretaceous in the eastern part of the Sturguel-Tchelopech strip. Ann. Univ. Mining and Geol., 23, 2-Geol., 7-30 (in Bulgarian with English abstract).

Stoykov, S., P. Pavlishina. 2004. Santonian-Campanian red beds in the northern part of the Central Srednogorie zone, Bulgaria. - In: Meliente, M. C., T. Brustur, D. Jipa, S. Szbotka (Eds.), IGCP 463 and 494 Workshop, Romania, Abstract Volume, 26-28.

Stoykov, S., I. Peytcheva, M. Frank, D. Fontignie. 2004. Timing and magma evolution of the Chelopech volcanic complex (Bulgaria). - Schweiz. Mineral. Petrograph. Mitt., 84, 101-117. 